\title{
ILLUSTRATIONS
}

PLATES following page 213.

I Mountain landscape, Hua-shan. (Photo by Hedda Morrison)

2 Mountain landscape, Hua-shan. (Photo by Hedda Morrison)

3 Mountain landscape, Hua-shan. (Photo by Hedda Morrison)

4 Omei-shan, Szechwan.

\section{WARRING States}

5 Silk square excavated at Changsha, Hunan. (Redrawn.)

6 Detail of painted decoration on bronze mirror. Fogg Museum of Art, Cambridge, Mass.

6a Painted decoration around a cylindrical lacquer box excavated at Changsha.

7 Detail of decoration on side of lacquer lien excavated at Changsha.

8-II Details of decoration on inlaid bronze hu. Palace Museum, Peking.

I2 Inlaid decoration on side of bronze lien. Museum of Fine Arts, Boston.

I3 $a-c$ Engraved decoration around inside of bronze ewer excavated at Changsha. (I $3 c$ redrawn.)

I4 Spout of engraved bronze ewer excavated at Ch'ang-chih, Shansi. (Redrawn.)

I5 Engraved decoration around inside of bronze lien excavated at Huihsien. (Redrawn.)

\section{Han Dynasty}

I6 Detail of wall painting in the Pei-yüan tomb, Liaoyang, southern Manchuria.

I7 Funerary clay house. William Rockhill Nelson Gallery of Art, Kansas City.

I8 Detail of painted decoration on clay house. William Rockhill Nelson Gallery of Art, Kansas City. 


\section{xii Illustrations}

I9 Detail of painted decoration on clay house. William Rockhill Nelson Gallery of Art, Kansas City.

20 Clay tile with painted decoration. Cleveland Museum of Art.

$20 a, b$ Pottery mortuary jar, with painted decoration over a white slip. (Dr. Paul Singer, Summit, New Jersey.)

2I Fairy mountain. Detail of painted lacquer bowl excavated at Lolang, Korea.

22 Pottery banner-stand (?) in the form of a fairy mountain, from a cave tomb in Szechwan. Szechwan University Museum.

23 Bronze steamer ( $p o$ ) with painted decoration. Museum of Fine Arts, Boston.

24 Bronze flask (pien-hu) with painted decoration. Museum of Fine Arts, Boston.

25 Bronze vessel (chung) with painted decoration. Museum of Fine Arts, Boston.

26, 27 Bronze vessel $(h u)$ with painted decoration. Museum of Fine Arts, Boston.

28 Sasanian silver platter. Detail. Hermitage Museum, Leningrad.

29 Embroidered shoe-sole found at Noin-Ula, Mongolia. Hermitage Museum, Leningrad.

30 a-c Cloud-scrolls depicted on painted lacquer objects.

3I Figured silk fabric from grave-pit at Loulan. Fogg Museum of Art, Cambridge, Mass.

32 Silk damask excavated at Noin-Ula. Hermitage Museum, Leningrad.

33 a-d Designs on inlaid bronze tube. Tokyo School of Art.

34 Decoration on inlaid bronze tube. Collection of the King of Sweden, Stockholm.

35 Woven silk panel excavated at Noin-Ula. Hermitage Museum, Leningrad.

36, 37 Stamped clay bricks.

38 Pottery jar with molded design. City Art Museum, St. Louis.

39 Glazed pottery $h u$ with molded design on shoulder. Collection of the King of Sweden, Stockholm. (After Palmgren.)

40 Pottery hill jar with molded design. Cleveland Museum of Art.

4I Pottery hill jar with molded decoration on side. Detail. Eugene Fuller Memorial Collection, Seattle Art Museum.

42 Glazed pottery $h u$ with molded decoration. Cleveland Museum of Art.

43 Bronze hill jar. Detail. Japanese collection.

44 Bronze tube with inlaid decoration. Hellström Collection, Stockholm.

45 Bronze lien with repoussé decoration. Freer Gallery of Art, Washington. 
46 Lid of pottery hill censer. Formerly C. T. Loo Collection.

47 a-e Lid of bronze hill censer. Details. Freer Gallery of Art, Washington.

48 Lid of bronze hill censer. Fogg Museum of Art, Cambridge, Mass.

49 Bronze mirror, TLV type.

50 Raising the bronze tripod of the Emperor Yü. Rubbing of an incised slab from Hsiao-t'ang-shan, Shantung. Detail of central shrine. Fogg Museum of Art, Cambridge, Mass.

5I Raising the tripod. Rubbing of a stone relief from Wu Liang Tz'u, Shantung. Detail.

52 Raising the tripod. Rubbing of a stone relief from an unknown site in Shantung. Detail.

53 Rubbing of an incised stone slab from Hsiao-t'ang-shan, Shantung. Detail.

54 The battle for the bridge. Rubbing of engraving on left end of main beam of tomb at I-nan, Shantung.

55 Rubbing of relief from Tu-chia-ch'uang, Shantung. Detail. Fogg Museum of Art, Cambridge, Mass.

56 Relief from unidentified site in Shantung. Detail.

57 Ts'ang Chieh and a companion beneath flowering trees. Detail of an engraved slab from tomb at I-nan, Shantung.

58 Gatehouse with trees beyond. Engraved slab from tomb at I-nan.

59 Calendar plant. Relief from Shantung. (Redrawn.)

60 Calendar plant. Relief from Shantung. (Redrawn.)

6r Mu-lien-li. Relief from unknown site in Shantung. (Redrawn by Feng Yün-p'eng.)

62 Relief from unidentified site in Shantung. (Redrawn by Feng Yünp'eng.)

63 Relief from Liu-chia-ts'un, Shantung. Detail.

64 Relief on funerary pillar from T'eng-feng-hsien, Honan. Detail.

65 Relief from T'eng-hsien, Honan. Detail.

66 Double interlaced tree. Relief from Tsining-chou, Shantung. Detail.

67 Interlaced tree. Relief from Tsining-chou. Detail.

68 Fu-sang tree (?). Relief from Tsining-chou. Detail.

69 Relief from T'eng-hsien region, Honan. Detail.

7o Relief from T'eng-hsien. Detail.

7r Stone slab from Liang-ch'eng-shan, Honan. Collection of the late Baron Von der Heydt, Ascona.

72 Stone relief from T'eng-hsien region, Honan. Detail.

73 Stone relief from T'eng-hsien, Honan. Detail.

74 Relief carved in honor of Li Hsi, A.D. I7r, Ch'eng-hsien, southern Kansu. 


\section{xiv Illustrations}

75 The chase among mountains. Relief on lintel of tomb at Nanyang, Honan.

76 Fabulous combat. Relief on lintel of tomb at Nanyang.

77 Animal combat. Relief on lintel of tomb at Nanyang.

78 Molded brick with scenes in relief.

79 Relief on vertical panel of tomb at Nanyang.

80 Molded brick with scenes in relief, Honan region.

$8 \mathrm{I}$ Relief on vertical panel of tomb at Nanyang.

82 Ram and ling-chih (?) on woven panel preserved in Shösöin Repository, Nara. Eighth century.

83 Molded brick with scenes in relief, from Honan.

84 Stone relief from tomb of Wang Te-yüan, Sui-te, Shansi. A.D. $x$ oo.

85 Po Ya and Ch'eng Lien. Rubbing of relief on side of stone coffer from Hsinchin, Szechwan.

86 A fabulous game of liu-po. Rubbing of relief on side of stone coffer from Hsinchin.

87 A fabulous scene. Rubbing of relief on side of stone coffer from Hsinchin.

88 The fu-sang tree. Rubbing of relief on side of stone coffer from Hsinchin.

89 Mythological scene. Rubbing of relief on side of stone coffer from Hsinchin.

90 Shooting and harvesting. Relief on a molded pottery tile from Yang-tzu-shan, Szechwan.

9I The salt industry of Tseliutsing. Rubbing of molded pottery tile from Yang-tzu-shan, Szechwan.

92 The salt industry of Tseliutsing. Rubbing of molded pottery tile from Yang-tzu-shan.

93 Boatman on a lake. Rubbing of molded pottery tile from Te-yang, Szechwan.

94 Driving along a road between trees. Rubbing of molded pottery tile from Yang-tzu-shan, Szechwan.

95 Ritual dance (?) in the fields. Molded pottery tile from Te-yang, Szechwan.

96 Woman in a grove of mulberries (?). Rubbing of molded pottery tile from Chengtu, Szechwan, dated A.D. 226.

97 Gatehouse. Rubbing of molded tile from Te-yang, Szechwan. 


\section{Six Dynasties}

98 Detail of wall painting in Tomb of the Wrestlers, T'ung-kou, Manchuria. Sixth century.

99 Detail of wall painting in Tomb of the Wrestlers, T'ung-kou. Sixth century.

roo Detail of wall painting in Tomb of the Wrestlers, T'ung-kou. Sixth century.

ror Detail of wall painting in Tomb of the Wrestlers, T'ung-kou. Sixth century.

I02 The Ruru Jataka. Detail of wall painting in Cave 257, Tunhuang. Ca. A.D. 500.

I03 The Ruru Jataka. Detail of wall painting in Cave 257, Tunhuang. Ca. A.D. 500.

I04 The Admonitions of the Court Instructress, after Ku K'ai-chih (ca. 345-ca. 406). Detail of hand-scroll, ink and slight color on silk. Late T'ang or tenth century.

105 The Tiger Jataka. Detail of wall painting in Cave 254, Tunhuang. I06 Mountainous landscape on lower part of ceiling of Cave 249, Tunhuang.

I07 Detail of lower part of ceiling of Cave 285, Tunhuang.

ro8 Detail of wall painting in "Ming-oi," Karashahr.

I09 Landscape detail in Cave 285, Tunhuang.

II Landscape detail in Cave 285, Tunhuang.

III A walled city. Detail of wall painting in the Three-chambered Tomb, T'ung-kou, Manchuria. $C a$. A.D. 500.

II2 Jataka scenes. Detail of wall painting in Cave 428 , Tunhuang.

II3 Jataka scenes. Detail of wall painting in the Cave of the Hippocamps, Kizil.

II4 Illustration to the Lo-shen $f u$, after Ku K'ai-chih. Detail of handscroll, ink on silk. Freer Gallery of Art, Washington.

II5 Detail of side of engraved stone sarcophagus. Minneapolis Institute of Arts.

II6 Detail of wall painting in Cave 302, Tunhuang.

II7 Detail of wall painting in Cave 296, Tunhuang.

II8 Detail of wall painting in Cave 296, Tunhuang.

II Detail of wall painting in Cave 296, Tunhuang.

I20 Painting on ceiling of Cave 4I9, Tunhuang.

I2I Detail of wall painting in Cave 209, Tunhuang.

I22 Detail of wall painting in Cave 217, Tunhuang. 


\section{xvi Illustrations}

I23 The story of the filial Wang Lin. Detail of engraved stone sarcophagus. William Rockhill Nelson Gallery of Art, Kansas City.

I24 The story of the filial Ts'ai Shun. Detail of engraved stone sarcophagus. William Rockhill Nelson Gallery of Art, Kansas City.

I25 The story of the filial Tung Yung. Detail of engraved stone sarcophagus. William Rockhill Nelson Gallery of Art, Kansas City.

I26 The story of the filial Shun. Detail of engraved stone sarcophagus. William Rockhill Nelson Gallery of Art, Kansas City.

I27 The story of the filial Kuo Chü. Detail of engraved stone sarcophagus. William Rockhill Nelson Gallery of Art, Kansas City.

I28 The story of the filial Yüan $\mathrm{Ku}$. Detail of engraved stone sarcophagus. William Rockhill Nelson Gallery of Art, Kansas City.

I29 Detail of painting on north wall of a tomb near Pyongyang, Korea.

I30 Illustrated version of the Ingakyō Sutra of Cause and Effect. Detail of Tempyō copy of a Suikō or Chinese Six Dynasties original. Jōbonjendaiji, Kyoto.

I3I Illustrated version of the Ingakyō Sutra of Cause and Effect. Detail of Tempyō copy of a Suikō or Chinese Six Dynasties original. Jöbonjendaiji, Kyoto.

I32 Detail of painting on baldachin over central Buddha figure in Kondō, Hōryüji, Nara.

I33 Decorated panels on base of Tamamushi Shrine, Hōryüji, Nara. (Redrawn.)

I34 The Tiger Jataka. Detail of painting on base of Tamamushi Shrine, Hōryüji, Nara.

I35 Detail of wall painting in tomb in Korea. (Unidentified.)

r36 Detail of engraved stone slab from funerary "bed." William Rockhill Nelson Gallery of Art, Kansas City.

I37 Sasanian silver plaque. Hermitage Museum, Leningrad.

I38 Silver ornament excavated at Noin-Ula, Mongolia. Hermitage Museum, Leningrad.

I39 Rubbing of design on a stamped clay brick. Han Dynasty. Art Institute of Chicago.

I40 Rubbing of design on a stamped clay brick. Han Dynasty. Art Institute of Chicago.

I4I Rubbing of design on a stamped clay brick. Han Dynasty. Art Institute of Chicago.

I42 Rubbing of a stamped clay brick. Han Dynasty. Royal Ontario Museum of Archaeology, Toronto.

I43 Fu-sang tree. Rubbing of relief in Wu Liang tomb shrine. Detail. Han Dynasty. 


\section{Illustrations $x v i i$}

I44 Rubbing of a stamped clay brick. Han Dynasty. Royal Ontario Museum of Archaeology, Toronto.

145 Rubbing of a stamped clay brick. Han Dynasty. Royal Ontario Museum of Archaeology, Toronto.

I46 Stamped and painted clay tile. Han Dynasty. Royal Ontario Museum of Archaeology, Toronto.

I47 Rubbing of a stamped and painted clay tile. Han Dynasty. Fogg Museum, Cambridge, Mass.

I48 Clay half-tile from north China. Han Dynasty. Japanese collection.

I49 Assyrian cylinder seal. British Museum, London.

\section{TEXT FIGURES}

I. Motifs on Huai and Loyang mirrors. 20

2. Drawings showing development of landscape motifs from volute. $\quad 48$

3. Detail of woven silk panel from Noin-Ula.

4. The compartmented style on bronze vessels from the ancient Near East and China.

Mountain conventions at Ajanta.

5. Detail of Admonitions scroll and tenth-century (?) landscape compared with typical Six Dynasties and T'ang foliage conventions. I48

6. Detail (restored) of Han brick found at Bac-ninh, Tonkin. (After Janse.) 
